\title{
VIEWPOINTS
}

\section{The Four Pillars of Halal Crisis Management}

\author{
Marco Tieman*
}

This viewpoint is about how to prepare and respond to a halal crisis. In short, many companies are preparing for the wrong kind of crisis. Too many treat a halal issue and halal crisis as a foreign material problem, like finding metal or glass in food, for which a trade or public product recall is initiated with an apology. Poorly managed halal crises, however, hit the bottom line hard and can ultimately kill a company. Getting it right, on the other hand, can have positive effects; although probably not experienced during the crisis itself, a halal crisis can be an opportunity to improve trust, Islamic values, and networking. This could strengthen a halal brand, sales, and company market share. However, this is only possible with the right actions and communication. Here I argue that best practice halal crisis management is founded on four pillars: process, control, organisation, and information. This requires solid preparation and practice.

\section{The Problem}

Negative publicity about a halal incident becomes a threat to both sales and corporate reputation. In a highly connected world, a halal issue can easily snowball into a halal crisis. Companies should expect a halal crisis every 10 years, which could result in lost sales in the range of USD 10-50 million for multinational companies, USD 5-10 million for large companies, and up to USD 5 million for SMEs. Moreover, corporate reputation accounts for approximately 20 per cent of the market cap of a company; in terms of corporate reputation damages, therefore, the lost value associated with a halal crisis could easily be triple that of lost sales. So, how best to protect and optimise your halal reputation asset?

Halal issues and crises are different from other business incidents. Muslims today are less prepared to tolerate risk, whether real or perceived, and demand a near zero-risk halal environment. Furthermore, Muslims are intrinsically motivated to actively boycott brands that are deemed to be in violation of Islamic teachings. As a result, as compared to other corporate incidents, there is a far higher chance that a halal issue can escalate into a global halal crisis. 
A halal crisis is a situation where a corporate halal reputation is under attack, endangering the sales and possibly even the existence of a company. This situation demands quick action and communication from the brand owner to reaffirm halal authenticity and Islamic values. Evidence from previous halal issues and crises show that a brand owner cannot fully rely on a quick response from halal authorities, but must occupy the main driving seat and address any halal issue or crisis themselves.

One of the biggest challenges today for halal reputation management is the combination of artificial intelligence, content creation, and the ability to disseminate limitless amounts of news, whether genuine or fake. True or not true, perception becomes reality. Additionally, today brand owners have complex supply chain networks, where brands are produced in different geographical locations with the possibility of coupling and co-branding. The coupling of brands occurs when companies produce different brands of the same product at one location, using (partly) the same ingredients and the same production lines. In such circumstances, sourcing (ingredients), production, logistics, and supply chain-related halal issues could immediately affect multiple brands. Companies also practice co-branding between different brands at the levels of product (Vitamin D from DSM), outlet (Coca-Cola at McDonald's), and service (delivered by DHL). This exposes brands to correlation, where a halal crisis effecting one brand can spread to others, despite there being no technical evidence of causality between them.

There are different levels of halal risk management awareness and capability, where asset-rich companies typically have stronger disaster management capabilities and some sort of issue management structure in place. Asset-light companies and the service industry, on the other hand, are least prepared for a major crisis. Even those companies that have high awareness and capabilities, however, are often poorly prepared, treating halal issues as little more than a foreign material problem requiring a product recall. Evidence suggests such traditional responses are not effective with halal crises, which weaken brand trust, Islamic values, and networks.

Halal trust can be defined as a Muslim consumer's belief that a product or service is in accordance with their faith. The building blocks of halal trust are: logos, excellence (ihsan), transparency, authenticity, and intention (niyyah). Using halal certification bodies, a company needs to re-affirm halal trust during a crisis, especially regarding excellence, transparency, authenticity, and intention. During a crisis, Islamic values need to be re-emphasised and publicised by brand owners in accordance with the relevant religious schools of thought and local customs. If the halal integrity of a supply chain network has been compromised, the problem (e.g. supplier) should be removed and the overall network strengthened. 
A solid post-mortem is required of the halal assurance, issue management, and crisis management systems. This means, for example, introducing new standard operating procedures, purchasing specifications, contract terms, supply chain structures, and so on.

\section{A Halal Crisis}

With regards to halal issues in Muslim markets, a whirlpool easily becomes a maelstrom, with a vortex dragging companies under. The lifebuoy thrown by corporate communication often has no lifeline attached due to the many gaps in the halal crisis manual and in halal risk management. The trigger of a halal crisis, a halal issue, can be contamination, non-compliance, or a perception issue. In the case of contamination, consumers could be 'poisoned' with haram ingredients and wonder if they can trust the brand again. A non-compliance issue puts the halal status of a product in doubt, something Muslims should, according to their religion, avoid. With perception issues there is a possible mismatch between perceived brand image and the Islamic way of life.

All three of these halal issue classifications have the potential to snowball into a global halal crisis, where corporate halal reputations come under attack. This situation demands quick action and communication from the brand owner in order to reduce damage to sales and reputation. These three halal issue classifications require specific responses to prevent an issue progressing into a crisis. As time is of the essence, it is important to prepare responses to these three issues in advance, as part of halal issues and crises manuals. This allows for better decisions and responses during halal incidents, saving companies a lot of money.

\section{Best Practice Halal Crisis Management}

Best practice halal crisis management is founded on four pillars: process, control, organisation, and information.

\section{Process:}

- Halal reputation by design, creating excellence in halal authenticity, choice of halal certification body, messaging by companies, supply chain partners, and external stakeholders;

- Combination of individual and collective halal reputation management strategies. 


\section{Control:}

- Halal assurance system documentation;

- Prevention: risk assessment, supply chain (re)design, vertical and horizontal collaboration, and monitoring halal risk and reputation performance;

- Mitigation: solid risk mitigation and communication plan;

- Recovery: solid risk recovery and communication plan.

Also important within halal crisis management control is determining the halal risk profile of a company. The halal risk profile is based on:

- Food products requiring more extensive risk management than non-food products;

- Products that are animal-based requiring more extensive risk management than products that are non-animal based;

- Suppliers from non-Muslim countries requiring more extensive risk management than suppliers from predominantly Muslim countries;

- Logistics service providers and distributors in Muslim-majority countries requiring more extensive risk management than those in non-Muslim countries;

- Brands from non-Muslim countries requiring more extensive risk management than brands from predominantly Muslim countries.

\section{Organisation (of halal responsibilities):}

- Top Management: halal policy and objectives;

- Board Risk Committee/Risk Management: halal certification decision and halal risk reporting;

- Marketing: showing (or not) the halal logo on product packaging and halal branding, and marketing decisions;

- Halal Committee: halal assurance system implementation and management.

\section{Information}

- A halal supply chain management system or conventional supply chain system with a halal management module;

- Halal reputation measurement (reputation index);

- Halal risk report for management and Board Risk Committee. 


\section{Policy Recommendations}

One cannot be involved in the halal industry without a proper halal risk and reputation management system to protect both corporate halal reputation and licence to operate. A halal crisis can be an opportunity to strengthen corporate trust, Islamic values, and networks. However, this is only possible with the right action and communication in the face of an issue or crisis. Best practice halal crisis management is founded on four pillars: process, control, organisation, and information. These require solid preparation and practice.

Islamic countries should promote advanced halal eco-systems to better protect companies in the halal industry. This is particularly critical for companies in the food business using animal-based products, and for brands in non-Muslim countries. Halal ecosystems can take the form of advanced halal clusters, parks or zones where halal industries are located and collaborate within their own supply chain in order to obtain halal synergies. Company supply chains operating from halal eco-systems are more robust by design as they are better organised.

Companies that are halal certified, or are going for halal certification, should be educated about halal risk and reputation management. It is good to realise that companies that are halal certified are also exposed to halal incidents and crises. This aspect should be covered in halal standards training courses.

Finally, more qualitative and quantitative research is required in halal risk and reputation management, creating practical tools for industry to better prevent and manage halal crises.

\section{Notes}

* Marco Tieman is Adjunct Professor with the Faculty of Industrial Management, Universiti Malaysia Pahang (Malaysia). He obtained his Master's degree in industrial engineering (logistics) with the University of Twente (the Netherlands) in 1997 and his $\mathrm{PhD}$ in business management (halal supply chain management) with Universiti Teknologi MARA (Malaysia) in 2013. He is also the CEO of LBB International, an international supply chain management consultancy and research firm specialising in halal purchasing and supply chain management. He chaired the development of the international halal logistics standard (IHIAS, 0100:2010) under ICCI-IHI Alliance. He is the author of 'Halal Business Management: A Guide to Achieving Halal Excellence'. Marco Tieman can be contacted at: marco@lbbinternational.com. 